and 16 died. Of the second class 9 died. And of the third class 17 were cured, 2 improved, and 3 died; and of all, 152 remained at the end of the yean

With the limited resources for the cure of the insane in this Institution, without any permanent resident physician in the house, this is remarkable success. Measures are now in progress to obtain a farther grant from the State, which will enable it to purchase lands, put up shops, arrange the buildings, and procure all other facilities for the labor, occupation and amusernent of the patients, and engage such medical attendants and such a corps of assistants as are found in the most approved asylums in the country. The attention of the people and Legislature has been called to the great advantages and success of other institutions, and the deficiencies of this, and immediately the friends of the asylum set about the work of obtaining the necessary means for reform, and without any doubt we shall have, in the course of the year, as good a hospital for the insane in Kentucky as is found elsewhere.

Our two State medical schools flourish beyond all precedent. This in Louisville has two bundred and sixty students, and that at Lexington about the same number.

Louisville, Fєb. 8, 1842.

In baste, your friend,

E. J.

\title{
HOOPING COUGH AND VACCINATION.
}

[Communicated for the Boston Medical and Surgical Journal.]

Does the hooping cough, cured as it sometimes is by vaccination, produce an exemption from subsequent liability to the disease?

Cases.-In July, 1836, John Birdsall, aged 3t years, son of Rev. J. O. Birdsall, then of Monroe, Michigan, after exposure was taken with hooping congh well marked. The disease continued two weeks, when he was vaccinated. As soon as the vaccine disease began to affect the system, the cough subsided, but the vaccine disease tork a regular course. In due time, George Birdsall, still younger, took the disease of Jolun; the character of the cough was unequivocal. He was vaccinated, and as soon as the symptoms of vaccina developed themselves the cough subsided, and the vaccine disease went througli a regular course. In August, 1840, Mr. Birdsall having removed to Saline, Washtenaw Co., the disease prevailing there, and having two children in the meantime added to his family, Jolın and George and the two younger children all had unequirocal hooping cough. The infant died. No difference was discoverable in the cases. John and Grorge went through the course of the disease without modification. Mr. B. informs me that the children have never been re-vaccinated.

T. Southwortr.

Monroe, Mich., Jan. 26, 1842.

\section{DIGITALIS.}

Dr. Calvin Jones, of West Tennessee, a physician of age and experience, has sent us a paper designed to recal the attention of his breth- 